\title{
DIAGNOSIS OF FUNCTIONING \\ OF NATIONAL PARKS IN POLAND \\ IN THEIR SOCIOECONOMIC ENVIRONMENT
}

\section{BARTŁOMIEJ WALAS, ${ }^{1}$ WOJCIECH FEDYK, ${ }^{2}$ TOMASZ PASIERBEK, ${ }^{3}$ SANDOR NEMETHY ${ }^{4}$}

\footnotetext{
${ }^{1}$ The University College of Tourism and Ecology in Sucha Beskidzka, Leisure and Tourism Department e-mail: bartlomiej.walas@wste.edu.pl

${ }^{2}$ The University School of Physical Education in Wroclaw, Faculty of Physical Education, Department of Tourism e-mail: wojciech.fedyk@awf.wroc.pl

${ }^{3}$ The University College of Tourism and Ecology in Sucha Beskidzka, Leisure and Tourism Department Babia Góra National Park

e-mail: pasiertom@poczta.onet.pl

${ }^{4}$ University of Gothenburg, Department of Conservation

e-mail: sandor@gvc.gu.se
}

\section{JEL CODES}

KEYWORDS

ABSTRACT
Q5, Q26, Q34, Q56, Z32

national park, commune, socioeconomic environment, conflict, cooperation, local community

On the basis of surveys among employees and local community of all national parks in Poland, which were conducted on the basis of in-depth interviews and focus groups, identification and diagnosis of attitudes and the status of cooperation between park managers and the community of adjacent communes (local government, residents, entrepreneurs) were made. Using the PESTEL technique, areas requiring modification of legal regulations as well as building relationships with the environment were established, allowing effective and efficient development of a given national park. Subsequently, at further stages of research, management models of a designated area of sustainable development will be created with a given national park, including all stakeholders (park, residents, state forests, territorial self-government, Nature 2000, entrepreneurs and visitors) that will put the aforementioned stakeholders in the "win-win" position, as much as possible. 


\section{Introduction}

Declaration of the word Congress of National Parks ${ }^{1}$ from 1992 clearly indicates the need to establish relations and symbiosis of national parks (NP) with the local environment, but as various studies indicate (Babczuk, 2015; Bożętka, 1995; Hibszer, 2013; Hibszer, Partyka, 2009; Królikowska, 2007; Dynowska, 2016; Olko, 2011; Sawicki, Zaręba, 1998) not only from the point of view of achieving the objective of nature conservation but also cooperation contributing to the sustainable development of the area.

However, it is true that the conservation of resources also requires intensive activities due to excessive tourist traffic in some NP (Kruczek, 2017; Warcholik, Semczuk, 2011) which seems to be an easier phenomenon to control than mutual expectations of socio-economic nature of stakeholders. Therefore, managing a NP requires legal, organizational and relational optimization, in line with sustainable development of their location.

Since Poland's accession into the EU structures, there have been a lot of legal changes, such as the new Law on Nature Conservation (2004; Solon, 2005), which have led to changes in people's awareness, organizational and management changes as well as the relations with the local community and local technologies (Odrowąż-Pieniążek, Radziejowski, 2006; Skawiński, 2006; Woźniak, 1997). Local government administration is being granted more and more decision making competences in relation to protected areas. These changes call for a new model of functioning of Nature Parks, which will include dialogue with its scientific and research environment, local business, local community and local government. However, one must keep in mind the fact that each park has different conditions of functioning, and its management, including tourist traffic service, may vary from other parks. In order to implement the model it is crucial that national parks have proper national and social status, appropriate organization and an effective system and level of financing and management. One may get an impression that nature conservation is not a scientific but social and marketing problem.

\section{Research methodology}

The aim of the conducted research was to depict social attitudes, phenomena and conflict areas, opinions and positions of stakeholders towards the tools for the implementation of statutory objectives by the units managing national parks.

Diagnostic tests were carried out in all national parks in Poland, between September 2017 and February 2018, as a part of the commission of the Ministry of Science and Higher Education. The research technique was an individual in-depth interviews and it included the employees of park management (director or deputy director of NP, chief accountant, specialist in nature conservation) and representatives of the environment (municipalities: commune head or deputy, environmental

${ }^{1}$ Declaration of IV National Park Congress IUCN, Caracas 1992, quoted "Without the support of local communities, the protected areas will never fully achieve their goals. This support is particularly important in Europe, where protected areas are usually located in the vicinity of inhabited areas or overlap them territorially". 
protection officers, residents). A total of 230 interviews of 10-11 people "per park" were conducted. In order to identify the attitudes of stakeholders and the problems of functioning of NP, the FGI technique was used - a focused group interview (focus groups) with teams of the following parks: Drawa NP, Słowiński NP, Tatra NP and Kampinos NP. A similar formula was used to query the "surroundings" of the surveyed NPs, and thus four FGI sessions with local self-government authorities, representatives of residents, and business representatives. In total, 8 sessions of focus groups were conducted.

In the research, it was hypothesised that the focus of all these stakeholder groups is not the national park or local economy, but a balanced territorial area, shared by the interest and functioning of all its stakeholders (Figure 1).

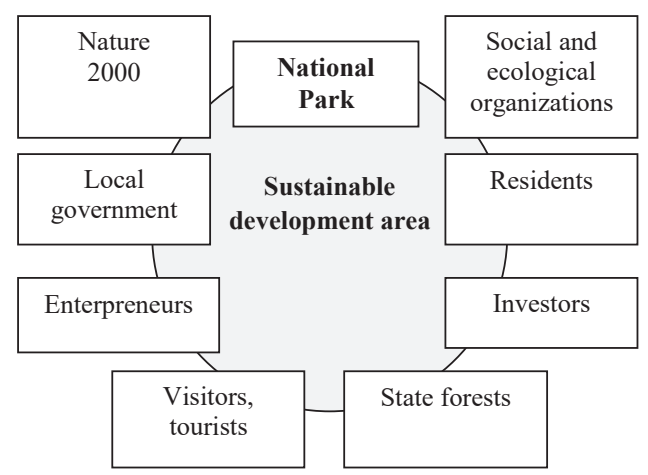

Figure 1. A hypothetical model of a sustainable area with a national park

Source: own study.

\section{Research results}

As a result of the research, mutual expectations, relationship status as well as problematic and conflict areas among the indicated types of stakeholders were diagnosed, and the obtained results will be the basis for a strategic diagnosis as a starting material for building NP optimization models at further stages of the research process.

The research carried out on two focus groups (representatives of parks and representatives of the "surroundings") indicated a strongly diversified assessment of the state of functioning of national parks in the context of their socio-economic environment (Tables 1 and 2). Clearly visible causes of fundamental differences of opinion (direct, prevailing statements of respondents) depend mainly on the location of the national park and the assessment of the consequences of their legal regulation or their status, but perhaps also on the personality of park managers and municipalities, which should be the subject of a deeper, further assessment in the research process. 
Table 1. Expectations and vision of the development of the national park from the perspective of the environment

Park is/causes/limits...
NP causes restrictions in the development of the commune,
depopulation.
The professionalism, knowledge and involvement of the employee
of NP are visible.
In the NP, the primacy of nature protection over human protection
is apparent.
NP acts as a tourist enterprise deriving significant income from
this. Meanwhile, the local self-government is deprived of this
income.
NP has too far-reaching powers resulting in limiting
investments, especially in the buffer zone; therefore, the NP
should participate in compensating for the development
of municipalities or investment restrictions should be
significantly reduced.

It is visible that NP is blocking the expansion of buildings owned by residents.

There is a lack of possibility to use NP natural resources in a satisfactory way (e.g. lack of admission of residents to obtain timber, forest undergrowth).

Conducting ecological activity is by all means a positive activity of NP.

NP applies the same rigors to the NP area and its surroundings (buffer zone).

The basic problem is that the local government receives too little compensation for "having" a NP in the commune area.

$\mathrm{NP}$ is interested in the smallest possible tourist traffic, which is contrary to the interests of residents.

Most of NPs are lacking funds.
Park should...

NP should conduct activities taking into account the values, resources and cultural development of the local community.

NP should coordinate its decisions with the public.

NP is running a business. However, the park's revenues also result from the fact of using municipal infrastructure. Therefore, the NP should share its income with the commune.

NP should allow the local residents to pick up mushrooms.

NP activities are understandable from the point of view of NP logic, but not from the point of view of recipients.

NP should be included in the structures of the self-government. As a consequence, NP revenues may be related to local government revenues.

The fact of the existence of a NP is something positive in the sense that there is an entity that organizes nature conservation and utilization of nature. However, the NP construction of functioning is faulty itself.

The NP directorate should be harnessed in the life of the local community and be associated with the development of this community.

Scientific research in NP is undoubtedly needed; the fact of financing them from the NP budget is a disputable matter.

Entry into the NP area should be paid, but the NP should share these revenues with the local community.

NP may be a driving force for the development of tourism provided that it is harnessed in the local economy and the interests of residents.

NP should take more into account the interests of the local community and especially the interests of entrepreneurs conducting tourist activities using the natural resources of the park.

There is no conflict between running a business and financing NP tasks from public funds. NP should have a stable source of financing and this can only come from public funds. On the other hand, conducting business activity by the NP should finance local development and support, for example, cultural heritage, tourism "industry", etc.

Source: elaboration based on own research

Table 2. Expectations and vision of the development of the national park from the perspective of its employees

\begin{tabular}{l} 
Park is/causes/limits... \\
\hline 1 \\
\hline \multicolumn{1}{c}{ Park should } \\
\hline $\begin{array}{l}\text { The NP protection plan, which is imposed by the law, is not ad- } \\
\text { equate to reality; it is prepared for } 20 \text { years and does not allow } \\
\text { to react to the changing nature, law or circumstances related to } \\
\text { the NP activity. }\end{array}$ \\
\hline
\end{tabular}


NP does not conduct any economic activity - the only activity is nature protection. There is no forestry - trees are not planted to be cut down, but to grow free (the same applies to fish and animals)

NP is left alone with financial matters

The forest service people have tax exemption, but there is no exemption for the park service people - it is not a good distinction because our tasks are similar.

Forestry services have procedures that have been developed for years - it is easier to manage. In NP, everyone has their own and each park has separate procedures, too. There is no formalization at the central level.

A legal state entity is a bad solution; if we were a budgetary unit , we would not have problems with VAT - then one could function better (it applies mainly to "poor" parks - deprived of tourists).

There is definitely a lack of different management tools that would be formalized at the central level.

No possibility of affecting the organizational structure of the park.

We can acquire more external funds as a legal state entity.

All legal tax bases (including VAT and income tax) incorrectly place the park as a form of enterprise, which obscures the image of the park.

Poor ecological awareness of residents, but relatively good ecological awareness of local governments.

The Nature Conservation Act leaves a lot of scope for over-interpretation in the field of land planning and management, which leads to many ambiguities and conflicts.

On the one hand, the constitution gives every citizen the right to use their property, and on the other hand, we have a law on nature protection that restricts the disposal of own property.

Forest fund supports NP in the implementation of conservation tasks (in financial terms) - without this, we would not be able to carry out the basic tasks of the park.

The existing research funding structure is not beneficial for the park and the scientific community.
There should be a separate protection plan for each NP - taking into account the specificity of a given park.

Maybe municipalities should spend their money on NP, and not receive a subsidy for the fact that the commune is located in the park.

The park should be able to have a greater impact on the shape of the nature conservation plan and conservation tasks.

NP should have an impact on the development - definitely more prominent in the park and in the buffer zone.

There are models of park management in the world that take into account greater social participation in its management. We do not have this obligation, but because we operate in a specific social environment, we try to make this participation and acceptance significant.

Delegation and decentralization of tasks.

Support and understanding of the local community.

Understanding by the partners of the core of strict (passive) protection and active protection.

Source: elaboration based on own research.

As a part of the research process, a series of theses and phenomena were presented to the groups of respondents for evaluation. They concerned the NP itself or its surroundings and the commune (Table 3). The obtained results point to such issues and areas, which clearly differentiate the respondents in terms of: the economic function of NP or limiting the availability of economic activity, whereas a set of precise conflicting actions has been identified (however, not represented in the article due to the volume of the text). Nature conservation specialists claim that the source of the presented controversies lies in increasing pressure on the use of natural resources of a given NP for economic purposes, the lack of effective landscape protection rules, in particular in the immediate vicinity, progressive spatial isolation of a NP as a result of uncontrolled urban development 
in the environment of the park and resulting in liquidation of natural ecological corridors. There is also no social climate for creating new national parks or for regulating the boundaries of the existing ones (Raj, 2018).

On the other hand, environmental stakeholders expect unconditional opportunities to run their own business and infrastructural investments, to limit the commercial activity they run (in their opinion) by the NP which is restricting the competitiveness, and the financial contribution of the park to the development of the commune. Seemingly contradictory positions indicate that the goal of all stakeholders should be the pursuit of compromise solutions, cooperation, respecting nature protection and economic development.

It is worth noting that the positions are not uniform, because even in the group of NP managers there are different assessments of the current legal status (which is: legal state entity). Also, the representatives of the environment are not in agreement either, or contradict themselves, in assessing the role of a NP in the development of the commune. One should look for reasons of this discrepancy in the specificity and local conditions of operation of each park, in the education financing system.

The location of parks, the ability of reception of tourist traffic, historically shaped conditions of ownership of land, the need to raise funds ${ }^{2}$ for the implementation of protective and educational tasks somehow forces some park managers to undertake tasks that are not always consistent with the expectations of the environment. However, they are not common, because, for example, collected opinions during focus tests clearly showed a positive perception of the park (Kampinos NP) or extremely negative (Słowiński NP).

Table 3. Level of compliance with hypothetical thesis from the perspective of employees (P) and representatives of the surroundings $(\mathrm{O})$ of national parks $(\%)$

\begin{tabular}{|c|c|c|c|c|c|c|c|c|c|c|c|c|c|c|c|c|}
\hline $\begin{array}{c}\text { Type } \\
\text { of respondent }\end{array}$ & $\mathrm{P}$ & $\mathrm{O}$ & $P$ & $\mathrm{O}$ & $P$ & $\mathrm{O}$ & $\mathrm{P}$ & $\mathrm{O}$ & $\mathrm{P}$ & $\mathrm{O}$ & $P$ & $\mathrm{O}$ & $P$ & $\mathrm{O}$ & $P$ & $\mathrm{O}$ \\
\hline 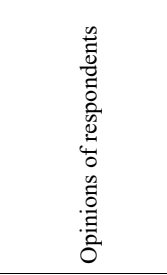 & \multicolumn{2}{|c|}{ 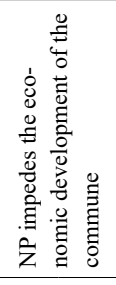 } & \multicolumn{2}{|c|}{ 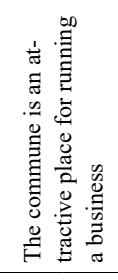 } & \multicolumn{2}{|c|}{ 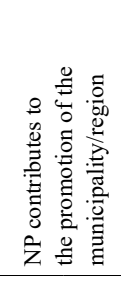 } & \multicolumn{2}{|c|}{ 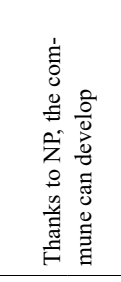 } & \multicolumn{2}{|c|}{ 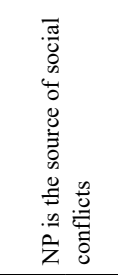 } & \multicolumn{2}{|c|}{ 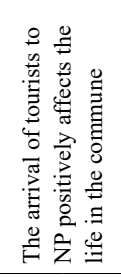 } & \multicolumn{2}{|c|}{ 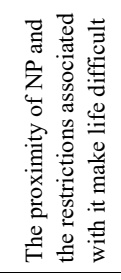 } & 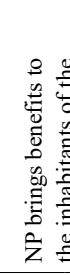 & 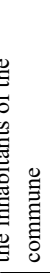 \\
\hline $\begin{array}{l}\text { I definitely } \\
\text { disagree }\end{array}$ & 48 & 12 & 2 & 1 & 2 & 5 & 4 & 8 & 14 & 13 & 1 & 2 & 27 & 12 & 0 & 5 \\
\hline I don't agree & 32 & 41 & 14 & 12 & 1 & 5 & 3 & 18 & 3 & 1 & 1 & 8 & 41 & 30 & 1 & 14 \\
\hline $\begin{array}{l}\text { I don't know/ } \\
\text { It's hard to say }\end{array}$ & 9 & 19 & 13 & 22 & 0 & 14 & 5 & 27 & 15 & 27 & 6 & 13 & 18 & 19 & 2 & 19 \\
\hline I agree & 8 & 18 & 43 & 41 & 18 & 39 & 44 & 33 & 0 & 29 & 35 & 48 & 11 & 23 & 39 & 46 \\
\hline $\begin{array}{l}\text { I definitely } \\
\text { agree }\end{array}$ & 3 & 10 & 28 & 24 & 79 & 37 & 44 & 14 & 9 & 10 & 57 & 29 & 4 & 16 & 58 & 16 \\
\hline
\end{tabular}

\footnotetext{
${ }^{2}$ The subsidy of the Ministry of the Environment is on average $30 \%$ of the budget.
} 
Continued Table 3

\begin{tabular}{|c|c|c|c|c|c|c|c|c|c|c|c|c|c|c|c|c|c|}
\hline $\begin{array}{c}\text { Type } \\
\text { of respondent }\end{array}$ & $\mathrm{P}$ & $\mathrm{O}$ & & $\mathrm{P}$ & $\mathrm{O}$ & $\mathrm{P}$ & $\mathrm{O}$ & $\mathrm{P}$ & $\mathrm{O}$ & $\mathrm{P}$ & $\mathrm{O}$ & $P$ & $\mathrm{O}$ & $\mathrm{P}$ & $\mathrm{O}$ & $\mathrm{P}$ & $\mathrm{O}$ \\
\hline 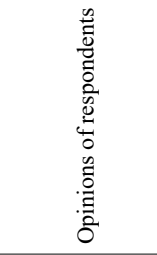 & \multicolumn{2}{|c|}{ 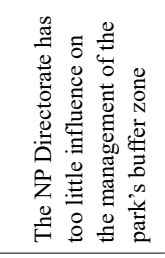 } & & 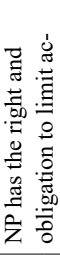 & $\begin{array}{l} \\
0 \\
\stackrel{\Xi}{ \pm} \\
\stackrel{0}{0} \\
0 \\
0 \\
0 \\
0 \\
0\end{array}$ & \multicolumn{2}{|c|}{ 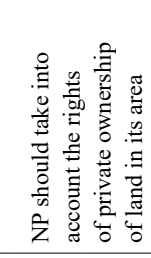 } & \multicolumn{2}{|c|}{ 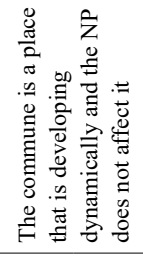 } & \multicolumn{2}{|c|}{ 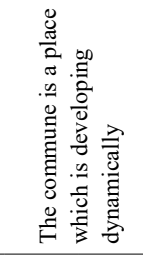 } & 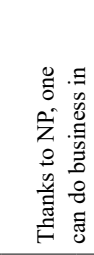 & 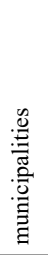 & \multicolumn{2}{|c|}{ 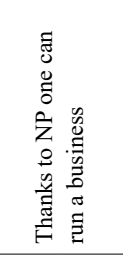 } & \multicolumn{2}{|c|}{ 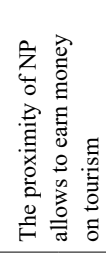 } \\
\hline $\begin{array}{l}\text { I definitely } \\
\text { disagree }\end{array}$ & 4 & 23 & & 10 & 12 & 4 & 3 & 13 & -* & - & 2 & 1 & - & - & 5 & - & 3 \\
\hline I don't agree & 15 & 26 & & 10 & 31 & 10 & 2 & 42 & - & - & 10 & 11 & - & - & 24 & - & 8 \\
\hline $\begin{array}{l}\text { I don't know/ } \\
\text { It's hard to say }\end{array}$ & 19 & 38 & & 8 & 12 & 17 & 24 & 23 & - & - & 27 & 19 & - & - & 35 & - & 10 \\
\hline I agree & 33 & 11 & & 23 & 33 & 36 & 33 & 17 & - & - & 37 & 39 & - & - & 27 & - & 54 \\
\hline $\begin{array}{l}\text { I definitely } \\
\text { agree }\end{array}$ & 29 & 2 & & 50 & 12 & 34 & 37 & 6 & - & - & 24 & 30 & - & - & 9 & - & 24 \\
\hline $\begin{array}{l}\text { Type of re- } \\
\text { spondent }\end{array}$ & $\mathrm{P}$ & $\mathrm{O}$ & $\mathrm{P}$ & $\mathrm{O}$ & & $P$ & $\mathrm{O}$ & $\mathrm{P}$ & $\mathrm{O}$ & $P$ & $\mathrm{O}$ & $P$ & $\mathrm{O}$ & $P$ & $\mathrm{O}$ & $\mathrm{P}$ & $\mathrm{O}$ \\
\hline 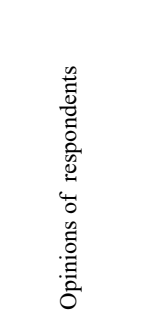 & 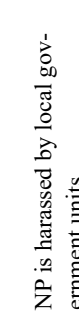 & & & 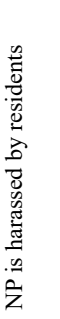 & & 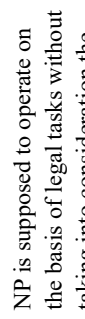 & 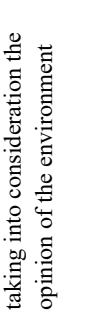 & 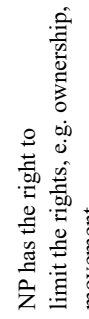 & 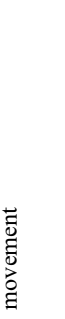 & 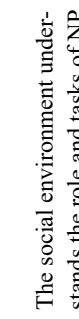 & & 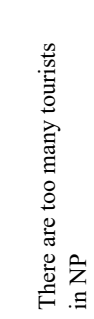 & & & 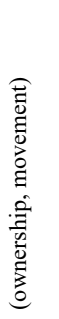 & & \\
\hline $\begin{array}{l}\text { I definitely } \\
\text { disagree }\end{array}$ & 26 & - & 15 & - & & 15 & - & 10 & - & 8 & - & 12 & - & - & 14 & - & 10 \\
\hline I don't agree & 38 & - & 44 & - & & 39 & - & 22 & - & 34 & - & 39 & - & - & 22 & - & 18 \\
\hline $\begin{array}{l}\text { I don't } \\
\text { know/It's } \\
\text { hard to say }\end{array}$ & 23 & - & 20 & - & & 14 & - & 13 & - & 28 & - & 15 & - & - & 21 & - & 29 \\
\hline I agree & 7 & - & 14 & - & & 23 & - & 35 & - & 27 & - & 20 & - & - & 35 & - & 28 \\
\hline $\begin{array}{l}\text { I definitely } \\
\text { agree }\end{array}$ & 5 & - & 6 & - & & 8 & - & 20 & - & 2 & - & 15 & - & - & 8 & - & 15 \\
\hline
\end{tabular}

" Lack of data results from the omission of a group of respondents in a given question.

Source: elaboration based on own research.

\section{Discussion}

The analysis of the obtained research results and a deepened interpretation of the conclusions from the literature review allow for a synthetic assessment of the conditions of functioning of national parks using the PESTEL method (Table 4).

The combination of environmental factors affecting the national park allows for an original attempt to assess their level of significance (from 0 to 10), the probability (weight) of occurrence 
(from 0 to 1) and the calculated expected value. ${ }^{3}$ The higher the expected value, the stronger the influence of a given environmental factor on the functioning of the national park.

The results of ranking environmental factors indicate that at the stage of building optimization models of the NP activity on the given area, the amendment of legal regulations will be necessary, both those directly related to the national park and nature protection as well as tasks specified in legal acts concerning local government. It seems at this stage of assessment of the results of the diagnosis that it will probably be a set of "hard" tools of even management and political character, the introduction of which will minimize the negative consequences of attitudes of both parties.

Table 4. Categories and ranking of the influence of environmental factors on the national park

\begin{tabular}{|c|c|c|c|c|c|c|}
\hline $\begin{array}{l}\text { NP sur- } \\
\text { round- } \\
\text { ing }\end{array}$ & Factor affecting NP & Characteristic of impact on NP & $\begin{array}{l}\text { The degree } \\
\text { of factor } \\
\text { influence } \\
\text { on NP }\end{array}$ & $\begin{array}{l}\text { The level } \\
\text { of impor- } \\
\text { tance of the } \\
\text { factor } \\
(0-10)\end{array}$ & $\begin{array}{l}\text { Probability } \\
\text { (weight) } \\
\text { of the factor } \\
\text { occurrence } \\
\quad(0-1)\end{array}$ & $\begin{array}{l}\text { Expected } \\
\text { value for } \\
\text { the factor } \\
(0-10)\end{array}$ \\
\hline 1 & 2 & 3 & 4 & 5 & 6 & 7 \\
\hline \multirow{3}{*}{ : } & $\begin{array}{l}\text { The formal meaning of the } \\
\text { superior unit, coordinating the } \\
\text { work of NP on behalf of the } \\
\text { Ministry of the Environment }\end{array}$ & $\begin{array}{l}\text { A strong unit in state administration } \\
\text { with adequate human resources coor- } \\
\text { dinating tasks and needs of NP }\end{array}$ & considerable & 7 & 0.7 & 4.9 \\
\hline & $\begin{array}{l}\text { Competences of the managers } \\
\text { of the protected area (NP, } \\
\left.\mathrm{LP}^{*} \text {, Nature } 2000, \operatorname{RDOS}^{* *}\right)\end{array}$ & $\begin{array}{l}\text { A clear and non-overlapping division } \\
\text { of competences }\end{array}$ & considerable & 7 & 0.8 & 5.6 \\
\hline & $\begin{array}{l}\text { Decentralization of manage- } \\
\text { ment competences in the } \\
\text { nature protection system }\end{array}$ & $\begin{array}{l}\text { Entrusting the right of decision to the } \\
\text { management of NP }\end{array}$ & considerable & 6 & 0.6 & 3.6 \\
\hline \multirow{3}{*}{ 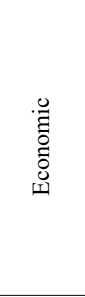 } & $\begin{array}{l}\text { NP financing - subsidy } \\
\text { indicator }\end{array}$ & $\begin{array}{l}\text { The current budget subsidy does not } \\
\text { cover even half of the NP's needs and } \\
\text { forces commercial activities that are } \\
\text { negatively perceived at the local level }\end{array}$ & decisive & 10 & 1.0 & 10.0 \\
\hline & $\begin{array}{l}\text { NP burdening with CIT and } \\
\text { VAT taxes }\end{array}$ & $\begin{array}{l}\text { The legal structure of NP does not al- } \\
\text { low VAT to be recovered and burdens } \\
\text { it with CIT tax }\end{array}$ & considerable & 8 & 0.8 & 6.4 \\
\hline & $\begin{array}{l}\text { Financing of NP tasks from } \\
\text { the Forest Fund }\end{array}$ & $\begin{array}{l}\text { An indispensable and supportive solu- } \\
\text { tion for financing NP tasks }\end{array}$ & considerable & 5 & 0.5 & 2.5 \\
\hline \multirow{5}{*}{$\begin{array}{l}\frac{\pi}{6} \\
0 \\
\dot{n}\end{array}$} & $\begin{array}{l}\text { Professional and social status } \\
\text { of a NP employee }\end{array}$ & $\begin{array}{l}\text { Low social status, lack of prestige } \\
\text { of the profession }\end{array}$ & small & 4 & 0.4 & 1.6 \\
\hline & $\begin{array}{l}\text { Local integration and identifi- } \\
\text { cation with NP activities and } \\
\text { sustainable development }\end{array}$ & $\begin{array}{l}\text { Significant diversity of many attitudes } \\
\text { depending on the NP location }\end{array}$ & decisive & 9 & 0.9 & 8.1 \\
\hline & Image of NP & $\begin{array}{l}\text { Diversified image of NP depending on } \\
\text { the group of stakeholders (residents, } \\
\text { entrepreneurs, tourists) }\end{array}$ & considerable & 7 & 0.8 & 5.6 \\
\hline & $\begin{array}{l}\text { Historically shaped owner- } \\
\text { ship of land in NP }\end{array}$ & $\begin{array}{l}\text { The legacy of nationalization } \\
\text { decisions is the reason for claims and } \\
\text { conflicts in NP until today }\end{array}$ & considerable & 7 & 0.7 & 4.9 \\
\hline & $\begin{array}{l}\text { The pressure of increasing } \\
\text { tourist traffic in NP }\end{array}$ & $\begin{array}{l}\text { Tourist traffic will grow and NP will } \\
\text { face an increasing problem of its } \\
\text { socially acceptable limitation }\end{array}$ & considerable & 8 & 0.8 & 6.4 \\
\hline
\end{tabular}

${ }^{3}$ Expected value (average, average value) defining the expected result after taking into account the probability of occurrence of the factor. 


\begin{tabular}{|c|c|c|c|c|c|c|}
\hline 1 & 2 & 3 & 4 & 5 & 6 & 7 \\
\hline \multirow{3}{*}{ 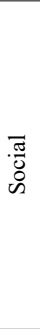 } & $\begin{array}{l}\text { The pressure to use natural } \\
\text { resources of NP for economic } \\
\text { purposes }\end{array}$ & $\begin{array}{l}\text { Pressure on NP in order to derive in- } \\
\text { come from business activities coming } \\
\text { into conflict with NP tasks }\end{array}$ & decisive & 9 & 1.0 & 9.0 \\
\hline & $\begin{array}{l}\text { Environmental awareness } \\
\text { of residents }\end{array}$ & $\begin{array}{l}\text { The level of awareness of the local } \\
\text { residents causes a lack of acceptance } \\
\text { for NP activities }\end{array}$ & small & 4 & 0.4 & 1.6 \\
\hline & $\begin{array}{l}\text { Local conditions of the func- } \\
\text { tioning of NP }\end{array}$ & $\begin{array}{l}\text { The differentiation of local conditions } \\
\text { of the functioning of NP causes that } \\
\text { the target model cannot be uniform } \\
\text { for all NPs }\end{array}$ & decisive & 10 & 0.9 & 9.0 \\
\hline \multirow{2}{*}{ 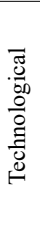 } & Monitoring in NP & $\begin{array}{l}\text { Necessary monitoring in NP based } \\
\text { on new technologies for monitoring } \\
\text { ecological and social phenomena } \\
\text { (tourist traffic) }\end{array}$ & small & 4 & 0.4 & 1.6 \\
\hline & $\begin{array}{l}\text { Uniformity of financial and } \\
\text { material software in NP }\end{array}$ & $\begin{array}{l}\text { Unification of IT and formal tools for } \\
\text { managing and financial management } \\
\text { in NP }\end{array}$ & small & 9 & 0.9 & 8.1 \\
\hline \multirow{3}{*}{ 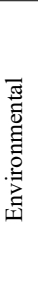 } & $\begin{array}{l}\text { Volunteering for the protec- } \\
\text { tion of nature in NP }\end{array}$ & $\begin{array}{l}\text { Creating a volunteer movement to } \\
\text { support ecological activities of NP }\end{array}$ & small & 7 & 0.8 & 5.6 \\
\hline & $\begin{array}{l}\text { Protection of endangered } \\
\text { species in NP }\end{array}$ & $\begin{array}{l}\text { Decentralization of decisions regard- } \\
\text { ing the protection of species in a given } \\
\mathrm{NP}\end{array}$ & considerable & 7 & 0.7 & 4.9 \\
\hline & $\begin{array}{l}\text { Lack of understanding for } \\
\text { the nature of strict (passive) } \\
\text { protection and active protec- } \\
\text { tion in NP }\end{array}$ & $\begin{array}{l}\text { The level of social attitudes, under- } \\
\text { standing for the operation of NP }\end{array}$ & decisive & 8 & 0.8 & 6.4 \\
\hline \multirow{3}{*}{ 茎 } & $\begin{array}{l}\text { The management of the NP } \\
\text { lands by the State Treasury }\end{array}$ & $\begin{array}{l}\text { Final resolution of land management } \\
\text { in the NP with compensation system }\end{array}$ & considerable & 6 & 0.7 & 4.2 \\
\hline & Spatial management planning & $\begin{array}{l}\text { Intertwining NP in spatial planning } \\
\text { decisions }\end{array}$ & considerable & 6 & 0.8 & 4.8 \\
\hline & $\begin{array}{l}\text { Legal status of NP and nature } \\
\text { protection }\end{array}$ & $\begin{array}{l}\text { Audit of legal status of NP and nature } \\
\text { protection solutions from the point } \\
\text { of view of contemporary phenomena } \\
\text { and modification of law }\end{array}$ & decisive & 9 & 0.9 & 8.1 \\
\hline
\end{tabular}

"State Forests.

${ }^{* *}$ Regional Directorate of Environment Protection.

Source: elaboration based on own research.

\section{Conclusions}

Against the background of the results of the performed research and analyzes, it seems justifiable to indicate a few key recommendations referring to the postulated changes in the functioning of national parks in Poland, in order to improve the effectiveness and efficiency of their activities from the perspective of the selected stakeholders.

Further organizational development of Polish national parks is necessary, in particular with regards to the hierarchy of the supervision and management system, as well as the legislative issues. It is necessary to develop and implement a more stable system of financing national parks, adequate to their role. The development and functioning of national parks should be a counterweight to the 
widespread consumerism in the scope of uncontrolled spatial development and excessive exploitation of natural resources.

The protection of the natural heritage of Poland, located within the borders of national parks, should obtain a real status and level of social acceptance, equivalent to the protection of historical and cultural heritage. It is necessary to develop an identity and social recognition, following the example of, say, American parks, as the "Service of National Parks" in Polish society. Further work on building the position of national parks in the awareness of Polish society through appropriate education, dialogue with the local community and promotion of Polish national parks is desirable.

Recommendations for the next stage of research on optimization models for the operation of national parks should be diversified for each of them, taking into account local conditions of the environment and expectations of stakeholders.

\section{References}

Act of April 16 2004, on the nature protection. Journal of Laws No. 92, item 880.

Babczuk, A., Kachniarz, M. (2015). Polskie parki narodowe - ujęcie instytucjonalne. Studia i Prace Wydziału Nauk Ekonomicznych i Zarzadzania, 40, 203-213.

Babczuk, A., Kachniarz, M. (2015). System finansowania parków narodowych w Polsce - stan obecny $i$ kierunki pożądanych zmian. Jelenia Góra: Związek Pracodawców Polskich Parków Narodowych.

Bożętka, B. (1995). Antropopresja na obszarze Wolińskiego Parku Narodowego na tle konfliktowości i problemu sąsiedztwa. In: A. Kostrzewski (ed.), Funkcjonowanie geoekosystemu Solińskiego Parku Narodowego w warunkach zmiany granic parku i narastającej antropopresji. Klify, Vol. 2, Międzyzdroje.

Hibszer, A. (2008). Od konfliktów do wspótpracy-wybrane aspekty przezwyciężania konfliktów społecznych w polskich parkach narodowych. Dokumentacja Geograficzna IGiPZ PAN, PTG, 37, 179-186.

Hibszer, A. (2013). Parki narodowe w świadomości i działaniach społeczności lokalnych, Uniwersytet Śląski, Katowice.

Hibszer, A., Partyka, J. (2009). Otulina parku narodowego - strefa ochronna czy strefa (potencjalnych) zagrożeń? Przykład Ojcowskiego Parku Narodowego. In: A. Andrzejewska, A. Lubański (eds.), Trwałość i efektywność ochrony przyrody w polskich parkach narodowych (pp. 55-65). Izabelin: Kampinoski Park Narodowy.

Królikowska, K. (2007). Konflikty społeczne w polskich parkach narodowych. Kraków: Oficyna Wydawnicza Impuls.

Kruczek, Z. (2017). Frekwencja w polskich atrakcjach turystycznych 2011-2015. Kraków: Proksenia.

Kulczyk-Dynowska, A. (2016). Przestrzenne i finansowe aspekty funkcjonowania obszaru chronionego - przykład Wolińskiego Parku Narodowego. Prace Naukowe Uniwersytetu Ekonomicznego, 418, 188-197.

Odrowąż-Pieniążek, I., Woźniak, J. (1997). Negocjacje, jako strategia rozwiązywania konfliktów w sporach pomiędzy parkami narodowymi a samorządami. Człowiek $i$ Środowisko, 1 (21), 87-95.

Olko, J. (2011). Ochrona przyrody w parkach narodowych Małopolski w świadomości wybranych grup społecznych. Praca doktorska. Kraków: Instytut Nauk o Środowisku, Uniwersytet Jagielloński.

Raj, A. (2018). Polskie Parki Narodowe- wspólne dobro. Materiał niepublikowany (prezentacja podczas warsztatu diagnostycznego).

Sawicki, J., Zaręba, D. (eds.) (1998). Społeczności lokalne a tereny prawnie chronione. Materiały z Warsztatów Terenowych. Kraków - Zawoja: PKE ZG SPN.

Skawiński, P. (2013). Percepcja społeczna ochrony przyrody w Tatrzańskim Parku Narodowym: wsparcie czy przeszkoda? Biuletyn Komitetu Ochrony Przyrody PAN, 61-69.

Solon, J. (2005). Czy obecna ustawa o ochronie przyrody jest dobrym narzędziem do rozwiązywania konfliktów „,człowiek - przyroda” w polskich parkach narodowych? In: A. Hibszer, J. Partyka (eds.), Między ochrona przyrody a gospodarka - blizej ochrony. Konflikty człowiek - przyroda w obszarach prawnie chronionych $w$ Polsce (pp. 9-17). Sosnowiec-Ojców: PTG Oddział Katowicki, Ojcowski Park Narodowy. 


\section{DIAGNOZA FUNKCJONOWANIA PARKÓW NARODOWYCH W POLSCE W OTOCZENIU SPOŁECZNO-GOSPODARCZYM}

SŁOWA KLUCZOWE

STRESZCZENIE park narodowy, gmina, otoczenie, konflikt, współpraca, społeczność lokalna

Na podstawie badań wśród pracowników i społeczności lokalnej wszystkich parków narodowych w Polsce przeprowadzonych w oparciu o pogłębione wywiady oraz grupy fokusowe dokonano identyfikacji i diagnozy postaw i stanu współpracy zarządzających parkami ze społecznością gmin przyległych (samorządem terytorialnym, mieszkańcami, przedsiębiorcami). Wykorzystując technikę PESTEL ustalono obszary wymagające modyfikacji regulacji prawnych oraz budowania relacji z otoczeniem, pozwalających na skuteczny i efektywny rozwój parku narodowego. Na tej podstawie na dalszych etapach badań powstaną modele zarządzania wyznaczonym obszarem zrównoważonego rozwoju z parkiem narodowym obejmujących wszystkich interesariuszy (park, mieszkańcy, lasy państwowe, samorząd terytorialny, Natura 2000, przedsiębiorcy i odwiedzający), które w możliwie największym stopniu postawią wskazanych interesariuszy w pozycji ,win-win". 